
VOLUME 10 NOMOR 6 DESEMBER 2021

ISSN : 2303-1514 | E-ISSN : 2598-5949

\title{
POLA ASUH DEMOKRATIS ORANG TUA DALAM MEMBERIKAN MOTIVASI BELAJAR SISWA SELAMA MASA PANDEMI COVID-19
}

\author{
Ainur Rohmania ${ }^{1}$, Deka Setiawan ${ }^{2}$, Khamdun $^{3}$ \\ ${ }^{123}$ Universitas Muria Kudus, Kudus, Indonesia \\ 1ainurrohmania9@gmail.com, ${ }^{2}$ deka170884@gmail.com, ${ }^{3}$ Khamdun@umk.ac.id
}

\section{PARENTS' DEMOCRATIC PARENTING PATTERNS IN PROVIDING LEARNING MOTIVATION FOR STUDENTS DURING THE COVID-19 PANDEMIC}

\begin{tabular}{|c|c|}
\hline ARTICLE HISTORY & ABSTRACT \\
\hline $\begin{array}{l}\text { Submitted: } \\
20 \text { April } 2021 \\
20^{\text {th }} \text { April } 2021\end{array}$ & $\begin{array}{l}\text { Abstract: This study aimed to determine how parents applied democratic parenting patterns in } \\
\text { providing learning motivation for students of SD Negeri } 2 \text { Rajekwesi Mayong Jepara during } \\
\text { the covid-19 pandemic. This study discussed how the democratic parenting style of parents } \\
\text { motivated the children to learn. This study used a qualitative method with a case study } \\
\text { approach. The subjects in this study were students and their parents. Data collection } \\
\text { techniques used were observation, interviews, and documentation. The data analysis used was } \\
\text { descriptive data analysis. The results showed that during the covid-19 pandemic, the } \\
\text { democratic parenting pattern was applied by parents to motivate children's learning by } \\
\text { encouraging and supporting the children, accompanying the children while studying, } \\
\text { rewarding children, and giving positive advice. Based on the result of the study, it was } \\
\text { concluded that the democratic parenting style was very influential in providing learning } \\
\text { motivation for students of SD Negeri } 2 \text { Rajekwesi during the covid-19pandemic. }\end{array}$ \\
\hline
\end{tabular}

Keywords: learning motivation, covid-19 pandemic, democratic parenting

Accepted:

15 November 2021

$15^{\text {th }}$ November 2021

Published:

27 Desember 2021

$27^{\text {th }}$ December 2021
Abstrak: Penelitian ini bertujuan untuk mengetahui bagaimana pola asuh demokratis yang diterapkan oleh orang tua dalam memberikan motivasi belajar siswa SD Negeri 2 Rajekwesi Mayong Jepara selama masa pandemi covid-19. Penelitian ini membahas bagaimana pola asuh demokratis orang tua dalam memberikan motivasi belajar. Penelitian ini menggunakan metode kualitatif dengan pendekatan studi kasus, subjek dalam penelitian ini yaitu siswa dan beserta orang tua. Teknik pengumpulan data yang digunakan yaitu observasi, wawancara, dan dokumentasi. Analisis data yang digunakan adalah analisis data deskriptif. Hasil penelitian menunjukkan bahwa pada masa pandemi covid-19 pola asuh demokratis yang diterapkan orang tua dalam memberikan motivasi belajar anak dengan memberikan dorongan dan dukungan kepada anak, mendampingi anak saat belajar, memberi penghargaan kepada anak serta orang tua kerap memberikan nasihat-nasihat yang positif. Berdasarkan hasil penelitian dapat disimpulkan bahwa pola asuh demokratis orang tua sangat berpengaruh dalam memberikan motivasi belajar siswa SD Negeri 2 Rajekwesi selama masa pandemi covid-19.

Kata Kunci: motivasi belajar, pandemi covid-19, pola asuh demokratis

\section{CITATION}

Rohmania, A., Setiawan, D., \& Khamdun, K. (2021). Pola Asuh Demokratis Orang Tua Dalam Memberikan Motivasi Belajar Siswa Selama Masa Pandemi Covid-19. Primary: Jurnal Pendidikan Guru Sekolah Dasar, 10 (6), 1610-1615. DOI: http://dx.doi.org/10.33578/jpfkip.v10i6.8237.

\section{PENDAHULUAN}

Pada saat ini pandemi covid-19 berdampak pada kehidupan semua keluarga seluruh dunia, begitu banyak kegiatan saat ini yang terhenti khususnya pada pendidikan dan pembelajaran diminta berlangsung dirumah. Situasi saat ini tidak muda bagi siapapun khususnya bagi orang tua menghadapi masa- 
masa saat ini. Karena Covid-19 adalah suatu wabah yang dapat membawa dampak penyakit menular berupa infeksi pada pernapasan manusia yang disebabkan oleh virus. Oleh karena itu orang tua perlu bersikap luwes dalam menyikapi berbagai tantangan yang muncul ketika mengasuh anak dikarenakan orang tua sangatlah dibutuhkan dalam mendukung pendidikan anak, anak selama pembelajaran dirumah lebih sering dan lebih senang bermain dari pada belajar akan tetapi setiap anak diberi batasan-batasan dan tanggung jawab dalam aktivitas kesehariannya. Pengasuhan orang tua dapat mempengaruhi kebiasaan belajar anak baik dirumah ataupun disekolah karena orang tua merupakan guru pertama bagi anak.

Pola asuh orang tua adalah suatu cara terbaik yang dapat ditempuh orang tua dalam mendidik anak sebagai perwujudan dari rasa tanggung jawab kepada anak. sebagai orang tua menerapkan pola asuh terhadap anak memegang peran penting dalam menanamkan dan membina terhadap prestasi belajar anak. menurut Idrus (2012:52) mengatakan bahwa pola asuh orang tua adalah suatu cara orang tua untuk mengasihi, membina, merawat, mendidik dan menanamkan sikap kedisiplinan, etika agar anak memiliki kepribadian yang baik. Sejalan dengan pendapat Gunarso (dalam Maliki 2017:52) mengatakan bahwa pola asuh adalah cara orang tua bertindak, berinteraksi, mendidik, dan membimbing anak untuk mengarahkan anak. berdasarkan beberapa pendapat tersebut maka dapat disimpulkan bahwa pola asuh orang tua adalah interaksi antara orang tua dan anak untuk memberikan pengasuhan terhadap anak bertujuan untuk mendorong dan membimbing kepribadian anak. akan tetapi setiap orang tua mempunyai cara yang berbeda-beda untuk mendidik anak dalam keluarga satu dengan keluarga yang lainnya.

Menurut Suherman (Joni 2015:43) manyatakan bahwa terdapat 3 macam pola asuh orang tua dalam keluarga ialah pola asuh otoriter, pola asuh demokratis dan pola pola asuh permisif. Berbagai jenis pola asuh tersebut dapat digunakan oleh orang tua dalam memberikan pengasuhan pada anak-anaknya. Akan tetapi kemungkinan orang tua bisa melakukan kolaborasi ataupun variasi dalam mendidik anak-anaknya, Namun yang perlu diingat dan ditekankan disini bahwa apapun usaha orang tua untuk memberikan yang terbaik untuk keluarganya khususnya anakanaknya harus tetap mengutamakan hak-hak anak sebagai manusia yang berharkat dan bermartabat sesuai dengan bakat minat kemampuan dan kebutuhan anak. Pada masa pandemi covid-19 saat ini orang tua memberikan batasan-batasan dan tanggung jawab dalam aktivitas kesehariannya terhadap anak, oleh karena itu orang tua menerapkan bentuk pola asuh pada masa pandemi covid-19 dalam memberikan motivasi belajar dengan menggunakan bentuk pola asuh demokratis karena pola asuh tersebut lebih sering digunakan sebagai model pengasuhan yang paling ideal dalam keluarga.

Fadhilah (2019:250) mengatakan bahwa Pola asuh demokratis adalah dimana orang tua memberikan kebebasan pada anak untuk berkreativitas berbagai hal sesuai dengan kemampuan anak dan mendorong anak untuk mandiri akan tetapi diberi batasan dan pengawasan. Pola asuh demokratis adalah dimana orang tua mendorong dan mendidik anak dengan menerapkan peraturan-peraturan yang disetujui bersama serta tetapi tetap memperhatikan keadaan dan kebutuhan anak. serta pada pola asuh demokratis ini ditandai dengan adanya sikap terbuka antara orang tua dengan anaknya, orang tua memberikan dorongan yang positif untuk membimbing anak kearah yang lebih baik. Seorang anak dalam melakukan belajar memerlukan adanya dorongan tertentu agar kegiatan belajarnya dapat menghasilkan prestasi belajar yang sesuai dengan tujuan yang diharapkan. Salah satu faktor yang mempegaruhi motivasi belajar siswa adalah orang tua. Seorang anak dalam melakukan belajar memerlukan adanya dorongan dan perhatian dari orang tua. 
Motivasi belajar pada usia sekolah dasar dipengaruhi oleh beberapa faktor tertentu, adapun salah satu faktor yang dapat mempengaruhi semangat belajar siswa usia sekolah dasar adalah keluarga.

Menurut Slamet (Jamil 2014:90) menyatakan bahwa ada beberapa faktor-faktor yang dapat mempengaruhi motivasi belajar siswa ialah faktor internal dan faktor eksternal. Faktor internal ialah faktor yang bersumber dari dalam diri siswa contohnya seperti kondisi jasmani dan rohani, memiliki cita-cita, kemampuan siswa, perhatian dan lain-lain. Kedua faktor eksternal yaitu faktor yang berasal dari lua diri siswa contohnya seperti fasilitas belajar dan lingkungan keluarga. Motivasi dan belajar merupakan dua hal yang saling mempengaruhi anak. Motivasi belajar adalah dorongan semangat yang timbul dari dalam diri maupun dari luar untuk tetap melakukan belajar sehingga seseorang dapat memperoleh hasil belajar yang maksimal berkat dorongan semangat atau motivasi belajar yang tinggi. Sejalan dengan pendapat dari Sidik (2018:193) menyatakan bahwa motivasi belajar adalah dorongan internal dan eksternal pada siswa yang sedang belajar untuk membentuk perubahan tingkah laku. Sedangkan menurut Kompri (2015:4) mengatakan bahwa motivasi belajar adalah suatu dorongan dari dalam individu untuk melakukan suatu tindakan dengan cara tertentu sesuai dengan tujuan tertentu. Suarman (2018:5) menyatakan bahwa motivasi belajar adalah segala sesuatu yang ditujukan untuk mendorong atau memberikan semangat kepada sesorang yang sedang melakukan kegiatan belajar agar menjadi lebih giat dalam belajar untuk memperoleh prestasi belajar yang baik. Dari pengertian para ahli dapat ditarik makna bahwa motivasi belajar adalah suatu dorongan siswa untuk meningkatkan prestasi belajar.

Berdasarkan observasi dan wawancara yang telah dilakukan peneliti dengan siswa dan beserta orang tua siswa SD Negeri 2 Rajekwesi dan penelitian ini dilakukan dirumah masingmasing informan, menunjukkan bahwa pada masa pandemi covid-19 banyak siswa saat dirumah cenderung lebih sering menghabiskan waktunya untuk bermain hp dan nonton TV, Sedangkan penjalasan dari orang tua menujukkan bahwa orang tua dalam memberikan pengasuhan dan pendampingan kurang maksimal sehingga berdampak terhadap motivasi belajar. Berdasarkan uraian diatas penulis tertarik untuk mengetahui lebih jauh bagaimana pola asuh demokratis yang diterapkan orang tua dalam memotivasi belajar siswa SD Negeri 2 Rajekwesi selama masa pandemi covid-19.

\section{METODE PENELITIAN}

Penelitian ini menggunakan metode kualitatif dengan pendekatan studi kasus dan analisis data secara deskriptif. Menurut Yin (dalam Gunawan 2013:116) mengatakan bahwa pendekatan studi kasus adalah sebuah penelitian yang secara khusus menyelidiki fenomena kontemporer yang terdapat dalam konteks kehidupan nyata, yang dilaksanakan ketika batasan-batasan antara fenomena dan konteksnya belum jelas, dengan menggunakan berbagai sumber data. Selanjutnya dalam penelitian ini subyek yang digunakan ialah 5 siswa dan beserta orang tua SD Negeri 2 Rajekwesi. Alasan peneliti mengambil siswa SD Negeri 2 Rajekwesi dijadikan sempel karena berdasarkan data yang diperoleh bahwa siswa tersebut memiliki tingkat prestasi belajar dan motivasi belajar yang kurang. Penelitian ini dilaksanakan di rumah orang tua siswa SD Negeri 2 Rajekwesi yang terletak di Desa Rajekwesi Kec.Mayong Kab. Jepara Jawa Tengah. Pelaksanaan penelitian dilakukan pada tanggal 26-27 Agustus 2020. Dalam penelitian ini, peneliti menggunakan 3 teknik pengumpulan data yaitu observasi, wawancara, dokumentasi, dan pencatatan. Teknik analisis data penelitian ini menggunakan analisis data deskriptif kualitatif.

\section{HASIL DAN PEMBAHASAN}

Peneliti akan memaparkan hasil penelitian yang telah didapatkan dari siswa dan 
orang tua SD Negeri 2 Rajekwesi Kec. Mayong Kab. Jepara. Sumber data primer dalam penelitian ini adalah lima siswa dan beserta lima orang tua siswa. Sumber sekunder data-data yang diperoleh peneliti dari refrensi buku-buku dan pendukung lainnya. Adapun hasil penelitian ini melalui hasil dari observasi, wawancara, dokumentasi dan pecatatan yang dilakukan adalah sebagai berikut:

Berdasarkan hasil wawancara yang dilakukan peneliti dengan semua siswa dan orang tua dirumah masing-masing di Desa Rajekwesi menunjukkan bahwa pada masa pandemi covid-19 orang tua menerapkan bentuk pola asuh demokratis dalm mengasuh anak-anaknya dengan cara menerapkan aturan yang tidak bersifat mengekang dan memberikan kebebasan yang bertanggung jawab. Bentuk pola pengasuhan tersebut diterapkan orang tua dalam upaya memberikan pengawasan, batasan-batasan tertentu dan memberikan pendampingan terhadap anak namun tidak terlalu memberikan beban yang berat kepada anak atau bisa dikatakan orang tua lebih memberikan perhatian yang lebih kepada anak khususnya dalam hal belajar. Serta dalam pola asuh pengasuhan tersebut menjadikan anak untuk mandiri dan displin beraktifitas secara teratur terhadap belajarnya ketika dirumah.

Kemudian pada penjelasan informan bahwa ketika dirumah pada masa pandemi covid-19 anak diberikan kebiasaan-kebiasaan yang positif seperti dalam hal belajar, religius (mengaji dan sholat), kemandirian dan kedisiplinan ketika dirumah. Sehingga dalam kebiasaan tersebut anak akan terbiasa beraktivitas belajar secara teratur ketika dirumah dan orang tua mampu memberikan peranan yang positif terhadap anak. dengan adanya hal tersebut anak memiliki motivasi belajar dan aktivitas belajar yang cukup baik ketika dirumah. hal ini sejalan dengan pendapat Muhadi (2015:5) menyatakan bahwa pola asuh demokratis adalah pola asuh dimana orang tua mendorong anak untuk menjadi mandiri, tetapi tetap memberikan batasan- batasan pada perilaku anak. Menurut pendapat Reswita (2017:75) mengatakan bahwa pola asuh demokratis adalah pola asuh orang tua yang menumbuhkan keyakinan dan kepercayaan diri serta mendorong dan memberi kesempatan kepada anak untuk mandiri dan bertanggung jawab.

Selanjutnya berdasarkan temuan yang diperoleh dilapangan, bahwa lima orang tua siswa yang menerapkan bentuk pola asuh demokratis menunjukkan bahwa orang tua murid SD Negeri 2 rajekwesi mulai menerapkan pola asuh demikratis sejak kecil sehingga anak sudah nyaman dan terbiasa dengan pola asuh yang diterapkan. Dari kelima orang tua ini ada salah satu dari anak mereka yang termasuk kategori memiliki motivasi belajar yang rendah padahal sama-sama menerapkan pola asuh demokratis. Hal ini disebabkan karena dalam tingkat kecerdasan dari anak kurang, selain itu juga perilaku anak ketika dirumah lebih suka bermain dengan teman-temannya serta orang tua kurang pendampingan dan dorongan. Pada masa pandemi covid-19 saat ini apabila guru memberikan tugas anak tersebut jarang mengerjakan tugas dengan segara dan sering terlambat menyelesaikan tugas. Berbeda dengan empat anak yang orang tuanya sama menerapkan pola asuh demokratis pada masa pandemi covid-19, mereka cenderung memiliki motivasi belajar yang dikategorikan cukup tinggi. hal ini disebabkan karena anak mendapatkan perhatian, dorongan dan pendampingan yang penuh dari orang tua dan anak memiliki tingkat kecerdasan yang tinggi serta kebiasaan belajar ketika dirumah cukup baik. Dengan adanya sikap orang tua tersebut yang selalu memerhatikan kemajuan belajar anaknya sehingga mendorong anak untuk lebih semangat dalam belajar.

Penanaman pendidikan yang diberikan orang tua terhadap anak mampu memberikan dorongan terhadap motivasi belajar yang baik dan mampu menjadikan dampak yang baik bagi anak. menurut pendapat Restiani (2017:26) mengemukakan bahwa ciri-ciri tipe 
pola asuh demokratis adalah 1) orang tua mendorong anak, 2) kerja sama yang harmonis antara anak dan orang tua, 3) anak mendapatkan dukungan dengan baik, 4) orang tua akan membimbing dan mengarahkan anakanak mereka, 5) ada kontrolan orang tua yang tidak kaku. Ciri-ciri orang tua yang seperti itu merupakan refleksi dari kondisi kepribadian yang matang, dewasa, sehat dan normal. bentuk pola asuh demokratis tersebut diterapkan oleh orang tua pada masa pandemi covid-19 terhadap anak dengan tujuan memberikan kebebasan anak tetapi terdapat ketentuan yang tidak boleh dilanggar oleh anak seperti aktivitas belajar dan aktivitas beribadah mengaji dan sholat. Maka dengan adanya bentuk pola asuh yang diberikan oleh orang tua untuk anak dapat meningkatkan motivasi belajar anak yang tinggi.

Menurut Suarman (2018:5) mengatakan bahwa motivasi belajar adalah segala sesuatu yang ditujukan untuk mendorong atau memberikan semangat kepada seseorang yang melakukan kegiatan belajar agar menjadi lebih giat lagi dalam belajar untuk memperoleh prestasi yang lebih baik. Senada dengan pendapat tersebut Handayani (2019:20) mengemukakan bahwa motivasi belajar merupakan suatu keadaan atau kondisi yang mendorong seseorang untuk melakukan sesuatu kegiatan yang dilakukannya sehingga ia dapat mencapai tujuan. Maka dapat disimpulkan bahwa motivasi belajar adalah dorongan semangat yang timbul dari dalam diri dan dari luar siswa untuk melakukan aktivitas sehingga dapat memperoleh hasil yang maksimal. Kemudian berkaitan dengan motivasi belajar siswa yang memilki motivasi belajar tinggi mampu memenuhi kriteria dalam indikator motivasi belajar yang sesuai dengan pendapat sadirman (2016:83) a) Tekun menghadapi tugas, b) ulet menghadapi kesulitan, c) menunjukkan minat terhadap macam-macam masalah, d) lebih sering bekerja mandiri, e) tidak cepat bosan pada tugas-tugas yang diberikan rutin, f) dapat mempertahankan pendapatnya, g) tidak mudah melepaskan hal-hal yang diyakininya, h) senang mencari dan memecahkan masalah. Anak yang memiliki motivasi yang kuat maka akan mendorong dirinya untuk belajar dengan penuh semangat.

Berkaitan dengan hal tersebut maka dapat disimpulkan bahwa pola asuh demokratis yang diterapkan orang tua pada masa pandemi covid-19 mampu memberikan motivasi belajar yang tinggi pada siswa SD Negeri 2 Rajekwesi. Orang tua mampu memberikan pendampingan yang maksimal terhadap proses belajar, memberi dukungan kepada anak, serta kerap memberikan nasihat-nasihat sehingga mampu memberikan dorongan terhadap motivasi belajar yang tinggi pada masa pandemi covid-19.

\section{SIMPULAN DAN REKOMENDASI}

Berdasarkan hasil penelitian dan pembahasan yang telah dipaparkan sebelumnya, maka dapat disimpulkan bahwa orang tua siswa SD Negeri 2 Rajekwesi dalam memberikan pengasuhan terhadap anak pada masa pandemi covid-19 tetap memberikan kebebasan kepada anak untuk bermain akan tetapi terdapat batasan-batasan yang tidak boleh dilanggar oleh anak terutama dalam hal proses belajar. Orang tua siswa menerapkan pola asuh demokratis pada masa pandemi covid-19 dalam memberikan motivasi belajar anak dengan cara memberi dorongan dan dukungan kepada anak, mendampingi anak saat belajar, memberikan penghargaan kepada anak, serta orang tua kerap memberikan nasihat-nasihat positif yang berkaitan dengan belajar dan nilai-nilai religius seperti anak harus selalu beribadah dan mengaji secara teratur sehingga akan lebih mudah untuk meningkatkan motivasi anak dalam belajar.

\section{DAFTAR PUSTAKA}

Fadhilah, N. T., Handayani, D. E., \& Rofian. (2019). Analisis Pola Asuh Orang Tua Terhadap Motivasi Belajar Siswa. Jurnal Pedagogi dan Pembelajaran, 2 (2), 249-255. 
ISSN : 2303-1514 | E-ISSN : 2598-5949

Gunawan, I. (2013). Metode Penelitian Kualitatif Teori \& Praktik. Jakarta: PT Bumi Aksara.

Handayani, R. (2019). Pengaruh Lingkungan Tempat Tinggal dan Pola Asuh Orang Tua Terhadap Motivasi Belajar Siswa Sekolah Dasar. Jurnal Tunas Bangsa, 6 (1), 20-30.

Jamil, H., \& Fefri, I. A. (2014). Pengaruh Lingkungan Keluarga dan Motivasi Belajar Siswa Terhadap Hasil Belajar Akuntansi Siswa Kelas X SMK Negeri 1 Solok Selatan. Journal of Economic and Economic Education, 2 (2), 85-98.

Joni. (2015). Hubungan Pola Asuh Orang Tua Terhadap Perkembagan Bahasa Anak Prasekolah (3-5 Tahun) Di PAUD AlHasanah Tahun 2014. Jurnal Paud Tambasui, 1(1), 42-48.

Kompri. (2016). Motivasi Pembelajaran Perspektif Guru dan Siswa. Bandung: PT. Remaja Rosdakarya Offset.

Ilyas, S. H. (2019). Pola Asuh Orang Tua Dalam Mengembangkan Kreativitas Anak (Studi Di Desa Gondoriyo, Kec.
Bergas, Kab. Semarang). Jurnal pendidikan, 4(1), 50-60.

Maliki. (2017). Hubungan Pola Auh Orang Tua Terhadap Disiplin Belajar Siswa di SMPN Kubang. Jurnal Konseling dan Pendidikan, 5(1), 52-61.

Muhadi, A. I. (2015). Hubungan Pola Asuh Demokratis Terhadap Kemandirian Anak Di Taman Kanak-Kanak El-Hija Tambak Sari Surabaya. Jurnal Pendidikan Islam, 4 (1), 30-40.

Restiani, S., Saparahayuningsih, S., \& Mona, A. (2017). Hubungan Antara Pola Asuh Demokratis Dengan Kemandirian Anak Di Kelompok A Paud IT Bina Iman Kabupaten Bengkulu Utara. Jurnal Potensia, 2(1), 45-55.

Sadirman, A. M. (2016). Interaksi dan Motivasi Belajar Mengajar. Jakarta:PT Raja Grafindo Persada.

Suarman, J., \& Gimin. (2018). Pengaruh Lingkungan Keluarga Terhadap Motivasi Belajar Siswa Pada Mata Pelajaran Ekonomi Kelas X IPS SMA Negeri 1 Pangean. Jom FKIP, 5(2), 110. 